\title{
Effect of Smallholders Socio-Economic Characteristics on Farming Households' Food Security in Northern Nigeria
}

\author{
Olayemi S. Sennuga ${ }^{1,3} \quad$ Richard N. Baines ${ }^{1} \quad$ John S. Conway ${ }^{1} \quad$ Rhiannon K. Naylor ${ }^{2}$ \\ 1.School of Agriculture, Food and Environment, Royal Agricultural University, Stroud Road, Cirencester, \\ Gloucestershire, United Kingdom, GL7 6JS \\ 2.School of Rural Land Use and Management, Royal Agricultural University, Stroud Road, \\ Cirencester, Gloucestershire, United Kingdom, GL7 6JS \\ 3.Federal Ministry of Agriculture and Rural Development, Abuja, Nigeria
}

\begin{abstract}
Food security is indispensable prerequisite for the continued existence of mankind and his economic activities including adequate food production. The study examined the effect of smallholder socio-economic characteristics on farming households' food security in Northern Nigeria. Data for this study were obtained from 120 randomly selected farming households, using a structured questionnaire. The results revealed that $81.7 \%$ of the households considered themselves food insecure. Furthermore, the majority of households have low incomes and low educational attainment which usually affects food security. There was also a significant negative association between food security and education as well as government policies. The analysis shows that low levels of education and government policies affected rural households. The paper therefore recommended that government and other development agencies should enhance food security among smallholders' farmers and rural communities through farmer education, promoting labour-saving technologies and facilitating access to market information. In the same vein, the paper infers that Nigeria needs to come up with results oriented food policy which for now it lacks. The public policy makers must as a matter of urgency see food as an essential component of welfares and as such develop sufficient political will to achieve food increase in food production and eventually attain food security for all.
\end{abstract}

Keywords: household food security; household food insecure; smallholder farmers; Nigeria

DOI: $10.7176 / \mathrm{JESD} / 11-4-16$

Publication date: February $29^{\text {th }} 2020$

\section{Introduction}

In recent years, attention has been focused on strategies for eradicating food insecurity and hunger throughout the world. This was reflected in the 2030 Agenda of the United Nations' Sustainable Development Goals (SDG 2) (FAO 2017). Seventeen of the proposed SDGs asserted "ending hunger, achieving food security, improving nutrition and promoting sustainable agriculture"(United Nation 2015; Osborn et al. 2015); furthermore, the target listed under SDG 2 describes both the demand and supply aspects of food security.

The UN's objectives call for the doubling of agricultural productivity and the incomes of smallholder food producers, particularly indigenous peoples, family farmers, pastoralists and fishers. This is to be achieved through secure and equal access to land, other productive resources and inputs, the provision of the knowledge, financial services markets, and opportunities for value added and non-farm employment (UN-Habitat 2014; Brown 2016). The achievement of these targets is very important to eliminating hunger and food insecurity worldwide. In other words, it is imperative that smallholder farmers and their families have adequate access to the resources and inputs required to effectively engage in livelihoods that will enable them to produce crops and also purchase food, especially at times of short supplies and high prices. According to the United Nations (2014), there are nearly 800 million people who suffer from hunger worldwide and the vast majority are from developing countries. In Nigeria 26 million people are currently suffering from hunger and malnutrition, while 1.6 million children suffer from acute malnourished in the study area, Kaduna State (UNICEF 2016).

There is an urgent need for national governments of a number of countries to improve food security and nutrition over the next 15 years in response to the global challenge of fostering sustainability (Parra et al. 2015). The fundamental role of every nation is to working to urgently eradicate the increasingly prevalent interconnected root causes of poverty and hunger in the land (Ahmed 2009; Mirza et al. 2013).

The World Summit on Food Security defines food security as the condition in which "all people, at all times, have physical, social and economic access to sufficient, safe and nutritious food, which meets their dietary needs and food preferences for an active and healthy life" (FAO 2009; FAO, IFAD and WFP 2015).Scrutinising this definition critically, four pillars of food security are identified:

1. Food availability;

2. Economic and physical access to food;

3. Food utilization; and

4. Instability, which involves exposure to vulnerability and shocks, over time. 
The relationship between these pillars has been adapted from the theoretical framework proposed by the FAO (2014; Fig 1).

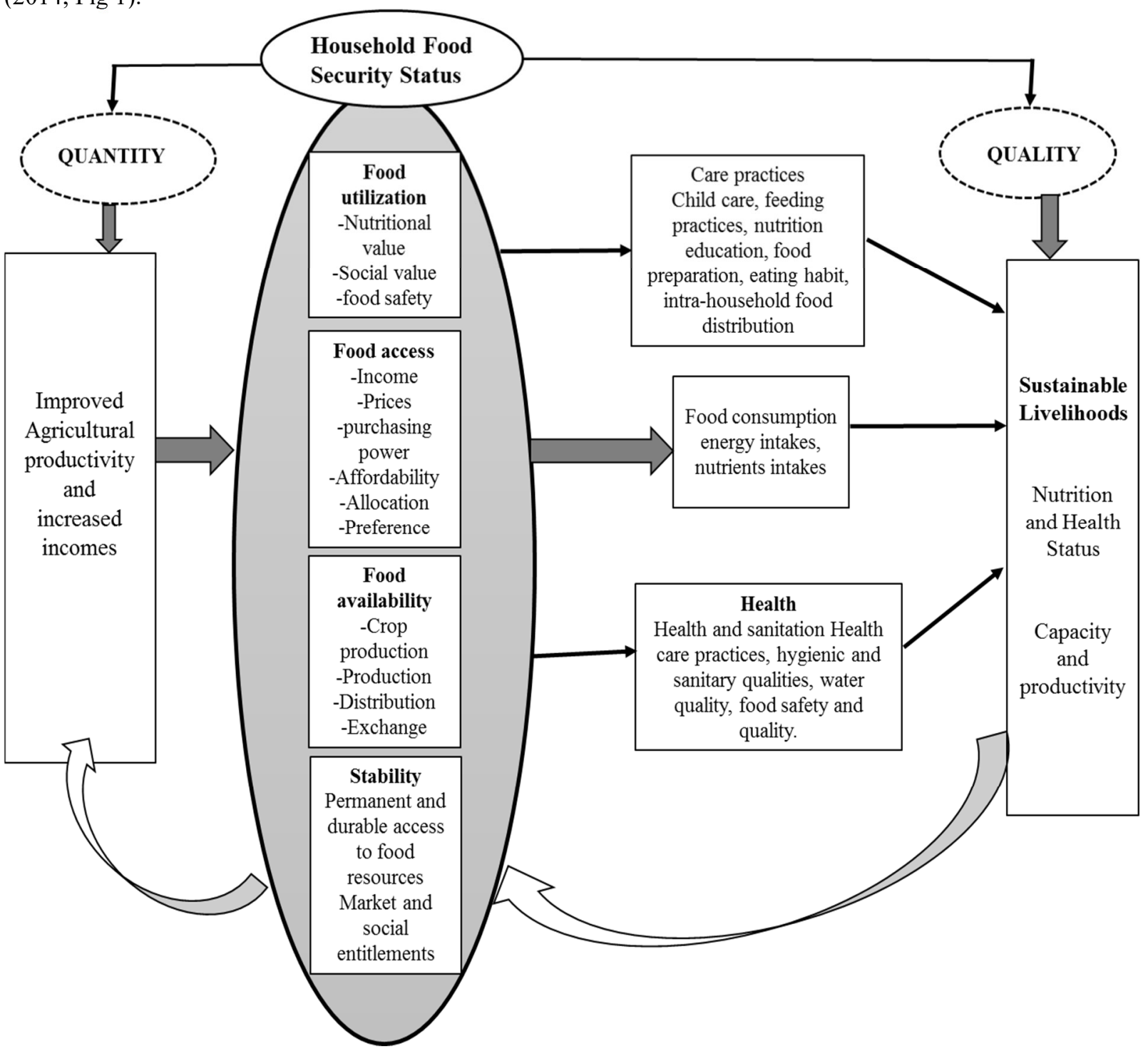

Figure 1: The Four Pillars of food security, a Conceptual Framework of Household Food Security (Adapted from FAO 2014)

Food security could also be described as access to a balanced diet and adequate nutrition for everybody. Food access is fundamentally interconnected with the adequate provision of foodstuffs, consequently, food security can be said to absolutely depend on a robust food system which comprises: production, allocation of supply, distribution, promotion, acquisition, and utilization of food (Mirza et al. 2013).

In Nigeria, chronic malnutrition is one of the underlying problems affecting the overall status and stability of the nation, particularly rural dwellers who are the major producers of crops. Nigeria is a food deficit country and is Africa's largest importer of rice. Children under the age of 5 have a $55 \%$ prevalence of stunting and $34 \%$ chance of being underweight in rural Nigeria, particularly in Northern region of the country due to endemic malnutrition (FAO 2013). In addition, displacement, high inflation and the consequent reduction in purchasing power of communities have worsened the food security situation in North-eastern Nigeria. According to the Global Nutrition Report (WHO 2016) over 3 million people are in urgent need of humanitarian assistance due to insurgency and abject poverty in Nigeria (Ojo and Adebayo 2012).

The socio-economic characteristics and resources of individual households have been recognized as the basic determinants influencing the food security status of smallholder households (Sanusi et al. 2006; Babatunde et al. 2007). Rural households continue to face poor economic conditions which contribute negatively to their standard of living and food security status. In the light of this, it's important that the socio economic conditions are recognised and understood in order to propose change. The objectives of the study were to: 
(1) Describe the socio-economic characteristics of the smallholder farmers.

(ii) Identify associations between a number of variables and food insecurity among smallholders.

(iii) Identify measures that could help ameliorate the level of food insecurity in the study area.

\subsection{Materials and methods}

This research was conducted in two randomly selected Local Government Areas of Kaduna State Nigeria (Figure 1). Two rural communities (Shika and Basawa) were selected from a sample frame of 18 villages using simple random sampling technique. From each village, a total of 60 smallholder households were selected using a simple random sample technique. The rationale and criterion for choice of the participants was based on their age, gender and farming experience. Thus, the total number of respondents interviewed for the study was 120 farming households. Personal interviews were conducted and a structured questionnaire was the major tool used for data collection. Closed and open ended questions were devised along with some ranking questions. The survey was piloted with three smallholder farmers who are working with Ahmadu Bello University, Zaria to check the reliability of the interview schedule. The data collected was analysed through descriptive and inferential statistics. The software SPSS version 24 was used which includes frequency distribution, percentage and correlations coefficient.

\subsubsection{Analytical techniques}

The descriptive statistical was used largely to describe the socio-economic characteristics of the respondents in relation to the farming household food security of the farmers. Pearson correlation coefficients analysis was used to identify the association between various variables and food security among smallholders' farmers' households.

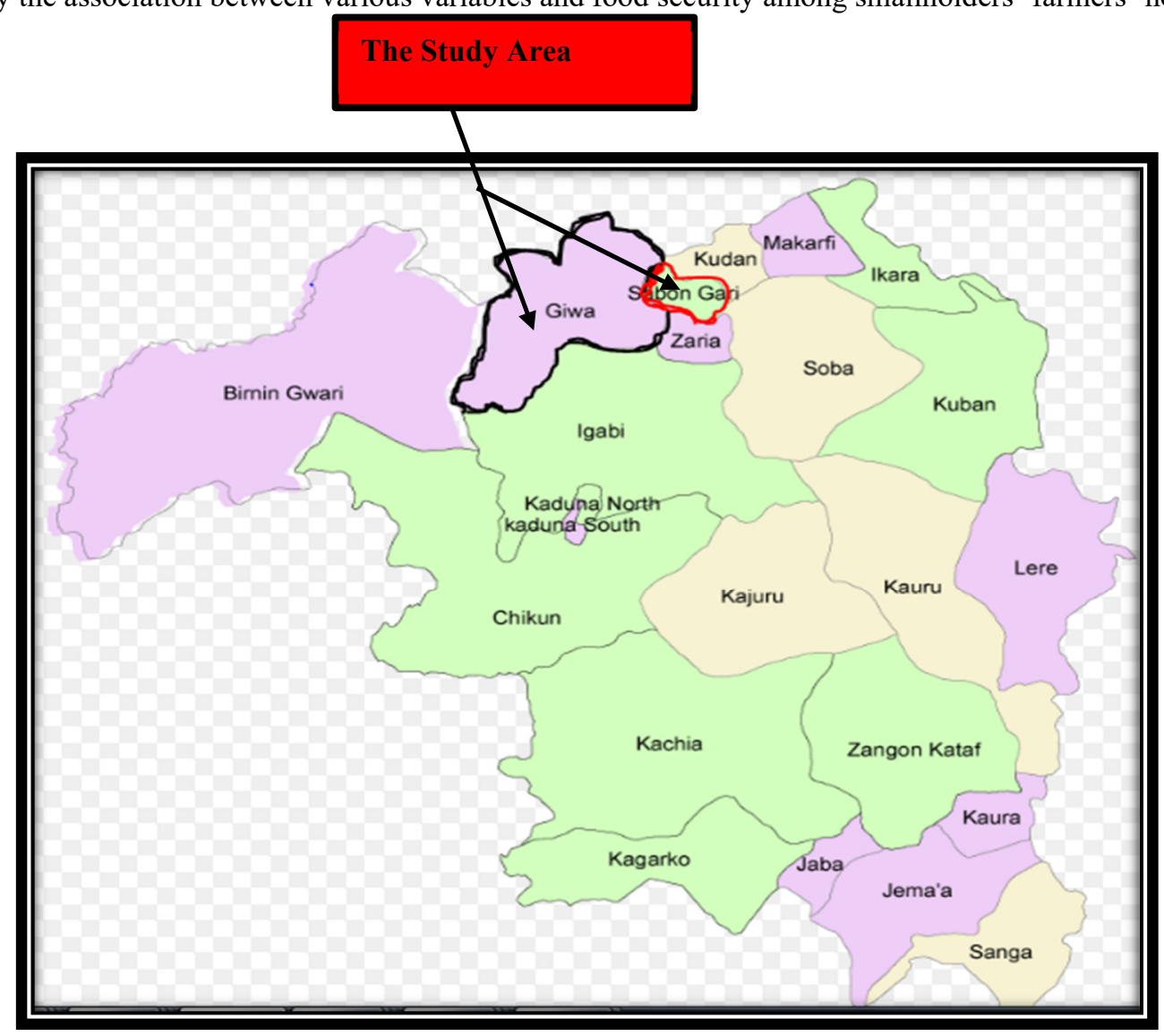

Figure 2: Map of the Study Area showing Giwa and Sabon Gari LGA, Kaduna State.

\subsubsection{Results and discussion}

The results initially profile the communities from the baseline survey before evaluating farming practices and then differences in their access to extension support including ICTs.

\subsubsection{Socio-economic characteristics of the respondent communities}

\subsubsection{Age of household heads}

Data in Table 1 revealed that $15.8 \%$ of the household heads were within the age group of $20-30$ years, while the overwhelming numbers of household heads (59.2\%) were in the middle age range of 31-50 years. This implies that the majority of the respondents were within their 'economic active age' and would possibly aim to improve 
their productivity and income in order to be food secure. It was also noted that $17.5 \%$ of the household heads fell within the age group of 51-60 years and $6.7 \%$ feel within $61-70$ years, while $1 \%(0.8)$ were above 70 years.

\subsubsection{Household Income}

The majority of households (91.4\%) had incomes less than $\$ 200,000$ per annum (636US Dollar) per annum, which showed that farming households are living within 1.4 US Dollars per day with their daily consumption expenditure below poverty line of 2 US Dollar recommended by World Bank (World Bank Report 2006). Poverty line is described as a borderline that distinguished poor from non-poor households in terms of their level of welfare. This study employed income approach method as a yardstick to set poverty line, that is, the total income of the households. The value computed by the survey was 636 US Dollar per annum. Hence, the farming households that earn less than 2 US Dollars World Bank poverty line were considered being poor, which is $91.4 \%$ of the sampled households. In addition, farming households considered themselves food insecure despite some house heads doing minor trading aside from the farming business. Only7.1\% of the households earned an average income $¥ 300$, 000.00 per annum (954 US Dollars) which is just 2.6 US Dollars per day. Thus, only $1.6 \%$ of the respondents were considered economically food secure.

\subsubsection{Household size}

Results in Table 1 indicate that $50.8 \%$ of the farmers had a household size of $1-10$ persons. Also, 34.1\% of the respondents had 11-20 dependants. In addition, $13.5 \%$ of the farmers had household size of 21 or more dependents. This implies that farmers have larger family sizes which could serve as an asset to the farmers in terms of the available work force. However, farmers in the study area are faced with the challenges of providing social and welfare facilities such as food provision, good education, sheltering, health care and other living expenses for their large number of dependants. The findings show that farmers were found to have low overall output and savings at the end of the farming season because most farm produce was consumed by family members.

\subsubsection{Marital status -}

Majority (90\%) of farmers were married with only $7.5 \%$ single and $2.5 \%$ were widowed. The very large percentage of married farmers could be attributed to the fact that respondents needed helping hands to carry out the monotonous process of farming activities. This is also implies that there is greater involvement of married people in farming activities in order to ensure household food security.

\subsubsection{Educational status of household heads}

Table 1 also indicate that $45.8 \%$ of the sampled farmers had no formal education, while about $32.5 \%$ of the respondents attended primary school. Only $14.1 \%$ of the farmers had secondary education, with $7.5 \%$ acquiring tertiary education. This implies that the majority of the respondents had low education attainment. This suggests that farmers' educational level is may negatively affect food security.

\subsubsection{Education level of Household members}

Majority (59.2\%) of the households interviewed have a member with at least a primary education, while 31.3 had\% household members with secondary education level; only $2.5 \%$ with tertiary education and $3.3 \%$ indicated that their households had no formal education. The very high percentage of household members in both primary and secondary education could be attributed to the free education scheme of the state government.

\subsubsection{Farming experience}

Majority of the farmers $(78.2 \%)$ have been farming for upwards of 10 years, while about $21.8 \%$ have less than 10 years of experience. Since farming is the major occupation in the study area, this infers that experience gained in farming can be linked with the age of the respondents. The older the farmer, the more experience he has and the better his understanding of farming practices; however, innovation is often associated with younger members of the community.

\subsubsection{Farm size}

Farm size is one of the determinants of labour requirements where studies have revealed that the larger the farm size, the more labour is required. The data shows that the majority $(59.2 \%)$ of the respondents in the study area have more than 2 hectares of farmland while $41 \%$ cultivated less than two hectares of land. The small farm size cultivated by smallholder may also influence rural households' food security negatively.

\subsubsection{Household labour utilization}

The results revealed the labour utilized by the households for their farming operations on a full and part time basis. The findings show that all the farmers used family labour as a good asset. About $45.9 \%$ of the respondents engaged the family members in full time with less than 5 family members and 6-10 members respectfully. Some 31.8\% of the farmers engaged their family members for farming operations on a part-time basis. Farmers explained that some of the household members are going to school and they only work according to their availability. Similar results were found by (Simon et al. 2014).

\subsubsection{Household Economic Assets}

A very high percentage of the respondents owned ICTs, with mobile phones (85.9\%) and radios (90\%) as the main household economic assets. Mobile phones and radio play a major role in diffusing information in rural communities, this implies that mobile phones and radios can help farmers make well informed decisions on 
adoption of GAPs and influence farmer's productivity positively if such information is provided. This could be attributed to the drastic fall of prices for mobile phones after Nigerian Government exempted VAT on handsets in 2003 (Sennuga 2012).

\subsubsection{Main Livestock Assets}

An overwhelming number (65\%) of households keep chickens while $24 \%$ and $33 \%$ of the farmers interviewed keep sheep and goats respectively. A sizeable proportion of the respondents $(32 \%)$ also indicated that they rear cattle and only $6 \%$ specified that they keep other livestock such as camels, ducks, turkeys etc.

\subsubsection{Most important crops}

The most important crops cultivated by the households in the study area included. As illustrated in Table 1, the findings indicate that maize $(35.8 \%)$, millet $(27.2 \%)$, cowpea $(14.0 \%)$ and groundnut $(13.3 \%)$ carried the lion shared. While sorghum, tomatoes and onions were also actively cultivated in the area, it implies that farmers were able to meet food supply of that household and were fully food secure even though they may have less to sell.

\subsubsection{Type of Irrigation used by farmers}

The findings reveals that $58.3 \%$ of the households interviewed used portable water pumps for their farming operations while $13.3 \%$ and $10 \%$ used sprinkler and bucket techniques respectively during the dry season. However, $12.2 \%$ of the farmers indicated that they do not use irrigation systems for their farming production. The erratic, late onset or early withdrawal of the rainy season in the study area has caused frequent crop failure, and approximately $47 \%$ of the farmers were adversely affected. This suggests that farmers using portable water pumps have unquestionably, the potential to improve their productivity and income. However, those farmers who do not use any irrigation system during the off season indicated that they engaged in some petty trading in the communities and its environment during the dry season.

\subsubsection{Access to crop inputs}

The results reveals that the main challenge farmers face are lack of capital/finance and insufficient fertilizers. This was perhaps due to the high costs reported by the farmers which were considered to be a very severe and serious problem affecting their access to crop inputs. This accounted for about $51.7 \%$ and $20 \%$ of the respondents respectively. The findings also indicated that the inadequate quality and adulteration of inputs, together with the distance from market were among the main challenges facing smallholders in the study area. This accounted for about $15 \%, 6.7 \%$ and $6.7 \%$ of the respondent respectively.

\subsubsection{Community access to extension}

As part of Government strategy on extension, key service providers were required to adopt a village (NAERLS 2012). With reference to the study area one village is adopted (Basawa) and one is non-adopted (Shika). Although the baseline study parameters discussed so far show no significant difference between the two communities, we would expect differences in relation to the extension effort (figure $2 \mathrm{a}$ and $\mathrm{b}$ ).

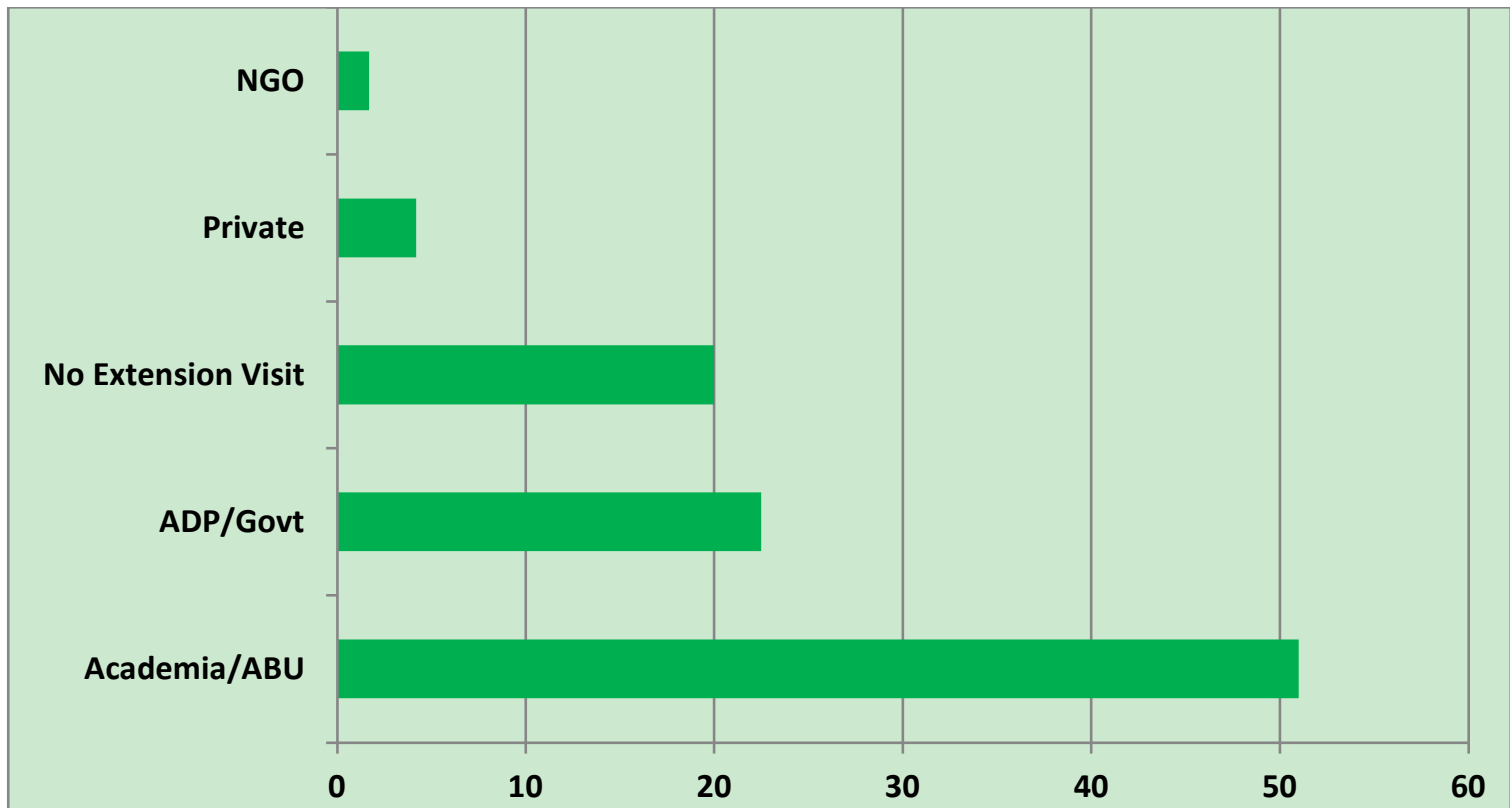

Figure 2a: Distribution of the respondents according to extension contact for Basawa Community (Adopted Village by NAERLS, ABU, Zaria) 


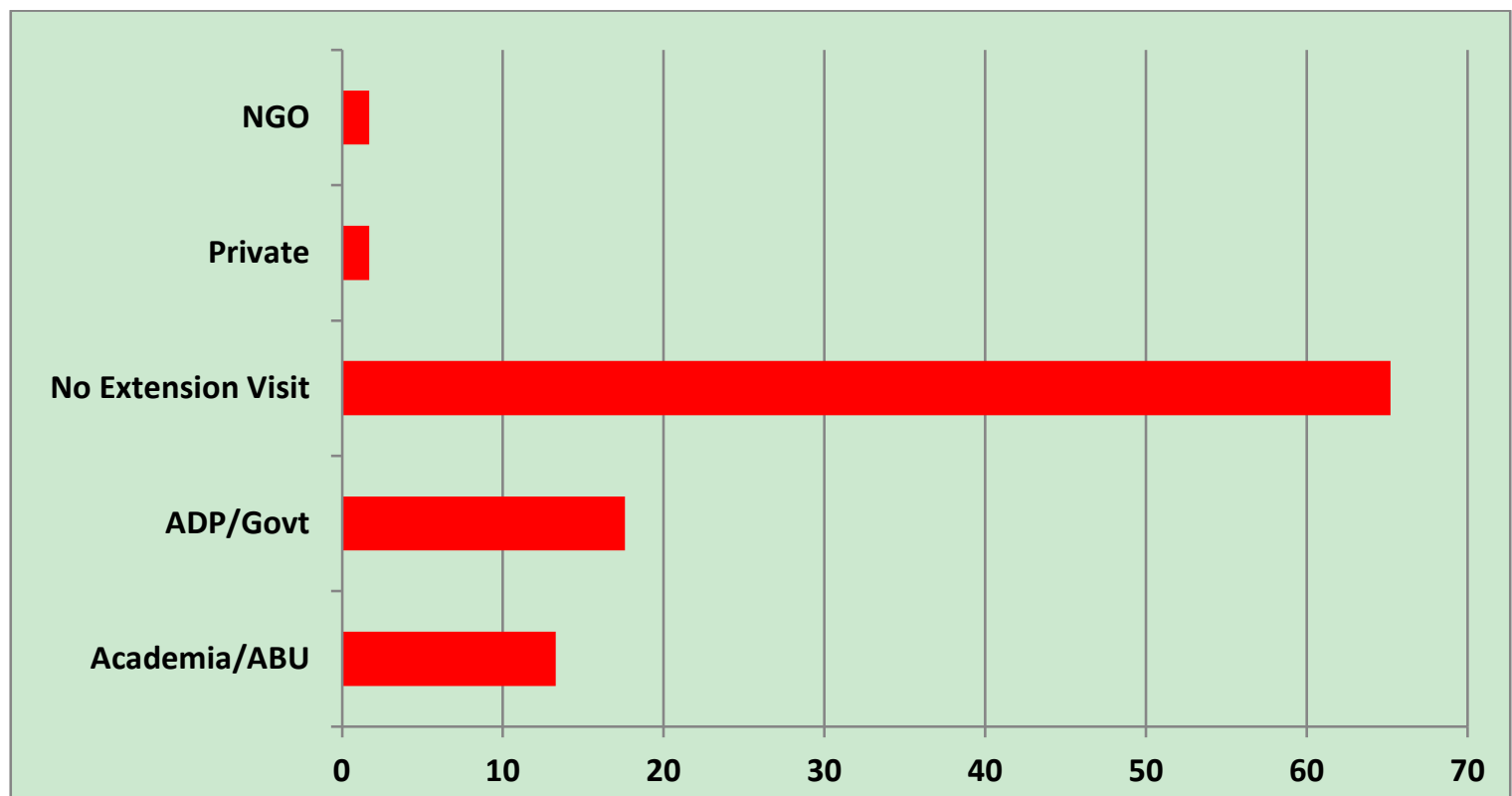

Figure 2b: Distribution of the respondents according to extension contact for Shika Community

(Non-Adopted Village)

As shown in figure $2 \mathrm{a}$, the majority $(51 \%)$ of the respondents from the adopted village (Basawa) received extension contact/visits regularly from NAERLS, while $22.5 \%$ of the farmers received extension visits from the $\mathrm{ADP} /$ Government agents only at the commencement of farming season. The results also show that $4.2 \%$ and $1.7 \%$ of the respondents had extension visits from the private sector and NGO's respectively. This implies that the overwhelming percentage of the farmers that received extension contacts could be attributed to the adopted village concept project initiated by the NAERLS, ABU, Zaria as part of its extension services delivery to farmers in the geo-political zone of Nigeria. However, only $20 \%$ of the farmers indicated that they do not receive extension visits.

From figure $2 \mathrm{~b}$, the findings of the respondents according to extension contact from Shika community (Nonadopted village) reveals that an overwhelming majority $(65.2 \%)$ of the farmers had no contact with extension personnel. $17.6 \%$ and $13.3 \%$ of the sample of the respondents reported that they had contact with extension personnel from the ADP/Government and academia but not as frequent as it ought to be. On the other hand, only two sample respondents reported that they received visits from the private sector and NGO's respectively. This implies that the non-adopted village (Shika) did not receive extension visit in comparison to the adopted village (Basawa).

In summary, the distribution of the respondents according to extension contacts from the case study clearly differentiated the two communities based on the adopted and non-adopted.

\subsubsection{Food Security}

The correlations coefficient (Pearson) (Table 2) shows that there is a negative association among income, education, government policies and food security, although there is a positive relationship between income and poverty which revealed significant results. Moreover, education and food security again actively exhibit a positive relation with poverty; however, government policies had a significant positive relation with food security. Farmers with low and average education tend to be low food insecure. While farmers with high education to be food secure. Also, farmers on high food security felt that government policy was satisfactory and good $75 \%$.

The relationship of food security with various variables were also carried out and the results are reported in (Table 2) which indicated a significant positive association between food security and education of the respondents. This implies that the higher the level of education of respondents there will be an increase in food security. Related results were found by Thomas et al. (2014) and Simon et al (2014) especially with regard to education.

However, income and poverty showed non-significant association with food security. Similar results were reported by Brown (2016). The data in the (Table 4) showed a non-significant correlation between income and food security. Food security is extremely low for high levels of income (7.14\%). Again, similar results were found by Brown (2016). However most people living in poverty are at risk of food insecurity, it cannot be pretended that they are, food secure. Indeed, for various reasons, including factors such as disability, inflation, ill health, sudden job loss and high costs of living, individuals above the poverty line cannot be assumed to be food secure.

Similarly, there was a non-significant association between poverty and food security. This suggests that beside the increase in poverty there is no increase in food security. Results in (Table 5) showed that the percentage steadily decreased for food security for high levels of poverty $(45.01 \%)$ and a high level of percentage for medium 
level of poverty (48.20\%). Similar results were established by Ngailo et al. (2016) and Mangisoni (2008) with respect to food security. However, opposing results were reported by Thomas et al (2014) in regards to income and food security.

Table 1: Distribution of the personal and demographic characteristics of smallholder farmers $(n=120)$

\begin{tabular}{|c|c|}
\hline Variables & Percentage \\
\hline \multicolumn{2}{|l|}{ Age (years) } \\
\hline $20-30$ & 15.8 \\
\hline $31-40$ & 32.0 \\
\hline $41-50$ & 27.2 \\
\hline $51-60$ & 17.8 \\
\hline $61-70$ & 6.7 \\
\hline$>70$ & 0.8 \\
\hline \multicolumn{2}{|l|}{ Gender (Sex) } \\
\hline Male & 100 \\
\hline Female & 0 \\
\hline \multicolumn{2}{|l|}{ Marital status } \\
\hline Single & 7.5 \\
\hline Married & 90. \\
\hline Widowed & 2.5 \\
\hline \multicolumn{2}{|l|}{ Household size } \\
\hline$\leq 10$ & 50.8 \\
\hline $1 \overline{1}-20$ & 34.1 \\
\hline $21-30$ & 13.5 \\
\hline$>31$ & 1.6 \\
\hline \multicolumn{2}{|c|}{ Household heads education } \\
\hline No education & 45.8 \\
\hline Primary & 32.5 \\
\hline Secondary & 14.1 \\
\hline Tertiary & 7.5 \\
\hline \multicolumn{2}{|c|}{ Family members education } \\
\hline No education & 3.3 \\
\hline Primary & 59.2 \\
\hline Secondary & 31.3 \\
\hline Tertiary & 2.5 \\
\hline No Children yet & 3.4 \\
\hline \multicolumn{2}{|l|}{ Farming experience } \\
\hline$<10$ & 21.8 \\
\hline $11-20$ & 32.0 \\
\hline $21-30$ & 27.6 \\
\hline $31-40$ & 18.3 \\
\hline \multicolumn{2}{|l|}{ Farm size } \\
\hline $1-2$ & 41.0 \\
\hline $3-4$ & 57.2 \\
\hline Above 4 & 1.8 \\
\hline \multicolumn{2}{|l|}{ Income (per annum) } \\
\hline$\$ 1-100,999$ & 17.5 \\
\hline$¥ 101,000-150,999$ & 34.2 \\
\hline$\# 151,000-200,999$ & 40.6 \\
\hline \# 201,000-250,999 & 5.3 \\
\hline$¥ 251,000-300,999$ & 1.8 \\
\hline$\# 301,000$ and above & 0.8 \\
\hline \multicolumn{2}{|c|}{ Household labour utilization } \\
\hline $1-5$ (Full time) & 45.8 \\
\hline 6-10(Full time) & 7.3 \\
\hline $1-5$ (Part time) & 31.8 \\
\hline 6-10 (Part time) & 14.2 \\
\hline
\end{tabular}




\begin{tabular}{|c|c|}
\hline Variables & Percentage \\
\hline \multicolumn{2}{|l|}{ Household economic assets } \\
\hline Radio & 90.0 \\
\hline Mobile phone & 85.9 \\
\hline Television & 5.8 \\
\hline Newspaper & 3.5 \\
\hline Computer & 0.8 \\
\hline Brochures & 0 \\
\hline Pamphlet & 0 \\
\hline \multicolumn{2}{|l|}{ Main livestock assets } \\
\hline Chicken & 65.1 \\
\hline Sheep/goat & 33.0 \\
\hline Cattle & 32.0 \\
\hline Camel & 1.6 \\
\hline Ducks & 2.1 \\
\hline Turkeys & 2.4 \\
\hline \multicolumn{2}{|l|}{ Most important crops } \\
\hline Maize & 35.8 \\
\hline Millet & 27.2 \\
\hline Cowpea & 14.0 \\
\hline Groundnut & 13.3 \\
\hline Potatoes & 10.0 \\
\hline \multicolumn{2}{|c|}{ Types of irrigation used by farmers } \\
\hline Portable water pumps & 58.3 \\
\hline Sprinkler & 13.3 \\
\hline Bucket & 10.0 \\
\hline Well & 2.4 \\
\hline \multicolumn{2}{|l|}{ Access to crop inputs } \\
\hline Lack of capital/finance & 51.7 \\
\hline Insufficient fertilizer & 20.3 \\
\hline Adulteration of inputs & 15.0 \\
\hline Distance from market & 6.7 \\
\hline Quality of Inputs & 6.7 \\
\hline
\end{tabular}

Table 2. Pearson Correlations Coefficient of various variables $(\mathrm{n}=120)$

\begin{tabular}{|c|c|c|c|c|c|}
\hline & Income & Education & Govt. policies & Food security & Poverty \\
\hline Income & 1.302 & & & & \\
\hline \multirow[t]{2}{*}{ Education } & -.136 & 1.302 & & & \\
\hline & .152 & & & & \\
\hline \multirow[t]{2}{*}{ Govt. policies } & -.090 & -.063 & 1.302 & & \\
\hline & .543 & 450 & & & \\
\hline \multirow[t]{2}{*}{ Food security } & -.142 & .164 & $.421 * *$ & 1.302 & \\
\hline & .158 & .057 & .030 & & \\
\hline \multirow[t]{2}{*}{ Poverty } & $.030 * *$ & $.570 * *$ & .570 & .178 & \\
\hline & .102 & .012 & .646 & .050 & 1.302 \\
\hline
\end{tabular}

***Correlation is significant at 0.01 level (2-tailed) * Correlation is significant at the 0.05 level (2-tailed). 
Table 3. Association between education and food $\operatorname{security}(\mathrm{n}=120)$

\begin{tabular}{|l|l|l|l|}
\hline Education & & Food Security & \\
\hline & Low & Average & High \\
\hline \multirow{2}{*}{ Low } & & & \\
\hline Average & 27.01 & 34.01 & 40 \\
\hline High & 31.12 & 32.10 & 20 \\
\hline
\end{tabular}

Table 4. Association between government policy and food security $(\mathrm{n}=120)$

\begin{tabular}{|l|l|l|l|}
\hline Government policy & \multicolumn{3}{|l|}{ Food Security } \\
\hline & Low & Average & High \\
\hline Poor & & & \\
\hline Satisfactory & 23.79 & 24.03 & 25.02 \\
\hline Good & 36.06 & 41.20 & 36.01 \\
\hline
\end{tabular}

Table 5.Association between income and food security $(\mathrm{n}=120)$

\begin{tabular}{|l|l|l|l|}
\hline Income & \multicolumn{3}{l|}{ Food Security } \\
\hline & Low & Average & High \\
\hline \multirow{2}{*}{ Low } & & & \\
\hline Average & 40.0 & 50.04 & 45.01 \\
\hline High & 50.0 & 44.05 & 48.20 \\
\hline
\end{tabular}

\section{Conclusion and Recommendations}

This paper has shown that a very large percentage of the respondents had low incomes and more than fifty percent of it was used on paying for food. The paper revealed that the socio-economic variables of the smallholder farmers are important factors for their food security. By and large, aside from income other important determinants are the education of the household's head and the large family size of the households are essential factors for food security among smallholder farmers. There was no reliable alternative job opportunity for the respondent except farming. Consequently, Government should endeavour to provide economic opportunities that will boost household income generation as well as take preventive measure to save crops from climate change and other natural disasters.

To achieve the Sustainable Development Goals (SDGs) of ending extreme poverty and hunger, achieve food security and improved nutrition and promote sustainable agriculture in Nigeria, it is recommended that food security strategies focus on and address the smallholder farmers as the largest producers of crops. Explicitly, Government should provide agricultural inputs for smallholders at subsidised and affordable prices as this will enable them to increase farm size and food production. Similarly, effort should be put into increasing household food production and trading. This would improve income generation and job creation opportunities, improve nutrition and food safety, increase the safety net and food emergency management systems, improve analysis and information management systems, and provide capacity-building. The provision of village infrastructures such as pipe-borne water, road network, electricity, and telephone lines etc. could increase off-farm activities that generate more income for rural households. Finally, government and other development agencies should enhance food security among smallholders' farmers and rural communities through farmer education, promoting labour-saving technologies and facilitating access to market information that would assist farmers to obtain higher market prices.

\subsection{Future Research Directions}

The paper suggests that research must not relent in their effort to proffer solution to the challenges of food security in Nigeria. On the other hand, favourable agricultural policies and the political will to create an enabling environment are needed to make research effort achievable and ensuring poverty alleviation. However, ICT will also provide a faster means of information dissemination and hold great potential for improving future agricultural productivity in Nigeria.

\section{References}

Ahmed, F. (2009). Food security in Pakistan, Pakistan Journal Agricultural Science, 46:2, 1-2. 
Babatunde, R.O, Omotesho, O.A. \& Sholotan, O.S. (2007). Socio-Economic characteristics and Food security Status of Farming Household in Kwara State, Northern-Central, Nigeria, Pakistan Journal of Nutrition, 6, 49-58.

Brown, M.E. (2016). Remote sensing technology and land use analysis in food security assessment, Journal of Land Use Science, 32, 1-19.

Eggbe, L. \& Leydesdorff, L. (2008). The relation between Pearson's correlation coefficient $r$ and Salton's cosine measure, Journal of the American Society for Information Science \& Technology, 1:2, 1-24.

FAO (2015). FAO and the 17 Sustainable Development Goals,

FAO (2015). Towards a Water and Food Secure Future Critical Perspectives for Policy-makers, http://www.fao.org/nr/water/docs/FAO_WWC_white_paper_web.pdf

FAO (2013). Panorama of Food and Nutritional Security in Latin America and the Caribbean. Rome, $30 \mathrm{pp}$.

FAO, IFAD \& WFP. (2015). The State of Food Insecurity in the World 2015. Meeting the 2015 international hunger targets: taking stock of uneven progress. Rome,FAO.Analysing Food Security Using Household Survey Data Ana Moltedo Nathalie Troubat Michael Lokshin Zurab Sajaia

FAO (2009). The Water-Energy-Food Nexus: A new approach in support of food security and sustainable agriculture. Rome.

FAO (2013). Social Protection for Food Security: A Report by the High Level Panel of Experts on Food Security and Nutrition: June 2012. HLPE Report 4. www.fao.org/fileadmin/user upload/hlpe/hlpe_documents/HLPE_Reports/HLPEReport-4-Social_protection_for_food_securityJune 2012. Pdf.

FAO (2017). The 2030 Agenda and the Sustainable Development Goals: The challenge for aquaculture development and management, by John Hambrey. FAO Fisheries and Aquaculture Circular No. 1141, Rome, Italy.

Hendriks, S.L. \& Oliviern N.J. (2015). Review of the South African Agricultural Legislative Framework: Food security implications, Development Southern Africa, 32, 555-576

Mangisoni J.H. (2008). Impact of treadle pump irrigation technology on smallholder poverty and food security in Malawi: A case study of Blantyre and Mchinji districts, International Journal of Agricultural Sustainability, 6:4, 248-266

Mirza, M.F., Badar, N.S., Hanif, M., Jabeen, A, Sadaf, G., Nauma, A., Shakeel, S., \& Munawwar, M. (2013). Effect of Socio-Economic Characteristics on Food Security on Small Scale Farmers in Rawalpindi, International Journal of Applied Science and Technology, 3:2, 87-91

National Agricultural Extension and Research Liaison Services (NAERLS), (2012). National report of Agricultural performance survey of 2011 wet season in Nigeria. Pp 182 - 185. ISBN: 978-978-51085-6-9.

Ngailo, S, Shimelis, H.A., Sibiya, J. \& Mtunda, K. (2016). Assessment of sweetpotato farming systems, production constraints and breeding priorities in eastern Tanzania, South African Journal of Plant and Soil, $33: 2,105-112$

Ojo, E.O. \& Adebayo, P.F. (2012). Food Security in Nigeria: An overview, European Journal of Sustainable development, 1:2, 199-222.

Osborn, D., Cutter, A. \& Ullah, F. (2015). Universal Sustainable Development Goals, Understanding the Transformational Challenge for Developed Countries Report of a study by Stakeholder Forum. https://sustainabledevelopment.un.org/content/documents/1684SF_-_SDG_Universality_Report_May_2015.pdf

Otaha, I. J. (2013). Food Insecurity in Nigeria: Way Forward an International Multidisciplinary Journal, Ethiopia, $4: 31,26-35$

Parra, D.C., Dinsmore, K., Fassina, N. \& Keizer, C. (2015). Toward SDG 2: Food Security and Urbanization in the Global South, the Centre for International Governance Innovation (CIGI) Graduate Fellows Series, Policy Brief, No 8.

Sanusi, R.A., Badejo, C.A. \& Yusuf, B.O. (2006). Measuring Household Food Insecurity in Selected Local Government Areas of Lagos and Ibadan, Nigeria. Pakistan Journal of Nutrition, 5: 62-67.

Sennuga, S.O. (2012). The application of Information and Communication Technologies to Small-scale Agriculture in Nigeria. An unpublished M.Sc Thesis submitted to School of Agriculture, Policy and Development, University of Reading, United Kingdom

Simon, O.L., Mwombe, F.I., Mugivane, I.S. \& Nderitu, J.H. (2014). Evaluation of Information and Communication Technology Utilization by Small Holder Banana Farmers in Gatanga District, Kenya, The Journal of Agricultural Education and Extension, 20:2, 247-261

Thomas, K., Rosenberger, J. G. \& Pawloski, L.R. (2014). Food Security in Bombardopolis, Haiti, Journal of Hunger \& Environmental Nutrition, 9:2, 230-243

UN-Habitat (2014). The State of African Cities 2014: Re-imagining Sustainable Urban Transitions. UN-Habitat Regional State of the Cities Report. http://unhabitat.org/the-state-ofafrican-cities-2014/ 
United Nations (2015). Transforming our world: the 2030 Agenda for Sustainable Development. Available at https://sustainabledevelopment.un.org/content/documents/7891 transforming our world.

World Bank Report. (2000). Attacking Poverty: the World Bank Development Report, Washington, by Oxford University Press, New York

World Health Organization (2014a). Global Nutrition Targets 2025: Childhood Overweight Policy Brief (WHO/NMH/NHD/14.6). Geneva. 